\title{
ВЛИЯНИЕ ЭКОНОМИЧЕСКИХ САНКЦИЙ НА СОЦИАЛЬНО-ЭКОНОМИЧЕСКОЕ РАЗВИТИЕ АРКТИЧЕСКИХ СТРАН
}

\section{(C) 2020 Богданова Анна Анатольевна}

кандидат экономических наук, доцент кафедры регионоведения, международных отношений и политологии

Северный (Арктический) федеральный университет имени М. В. Ломоносова, Россия, Архангельск E-mail: a.bogdanova@narfu.ru

Санкции в условиях глобализации являются одним из основных внешнеполитических инструментов и оказывают большое влияние на экономическое развитие страны путем ограничительных мер, заставляя государства, подверженные санкциям, идти на какие-либо уступки. Однако основной проблемой экономических санкций против России, является то, что страны, принявшие их, сами серьезно пострадали от данных ограничений.

Ключевые слова: экономические санкции, глобализация, арктический регион, социально-экономическое развитие.

Санкции как компонент принуждения во взаимодействии между странами или мировым сообществом и определенным государством на данный момент являются одним из основных внешнеполитических инструментов. В настоящее время все больше проявляется глобализация национальных рынков, их взаимозависимость. По этой причине санкции могут оказывать большое влияние на экономическое развитие страны путем ограничительных мер, заставляя государства, подверженные санкциям, идти на какие-либо уступки. «Мягкая сила» - одно из названий инструмента применения санкций, которое предоставляет возможность государствам-инициаторам добиваться осуществления своих целей без капиталоемкого примирения вооружений.

Санкции - меры принудительного экономического воздействия за нарушение установленного порядка деятельности, имеют предупредительную, компенсационную или репрессивную функцию и, как правило, окончательный, не подлежащий пересмотру характер [7].

Современные санкции являются очень неоднозначным внешнеполитическим инструментом, и в связи с этим его следует применять осторожно. Такое применение имеет на данном этапе определенные тенденции:

1. Значительно расширился ряд целей применения ограничений;

2. Практически всегда экономические санкции не могут нанести значительный ущерб экономике государства-объекта;
3. Экономические санкции применяются больше в сфере финансов, а не торговли;

4. Санкции используют наиболее часто сильнейшие экономические державы, прежде всего США.

Что касается экономических санкций в Арктике, первой из исследуемых стран против России их ввела Финляндия как член ЕС. Норвегия вскоре присоединилась к антироссийским санкциям [3].

Европейские санкции вводились в три этапа в течение 2014 года. В июле Европейский союз ввел запрет на покупку или продажу некоторых технологий, если они предназначены для освоения и развития арктического региона, в частности глубоководной разведки и добычи сланцевой нефти [3]. Понятно, что эта мера призвана ослабить положение РФ в арктическом регионе.

Также были введены санкции, тормозящие освоение и развитие арктического региона: запрещено предоставление технической и юридической помощи странами-членами Евросоюза, если она связана с нефтедобычей в данном регионе; ограничена продажа товаров, оказание финансовой или транспортной помощи (возможна только при получении соответствующего разрешения); запрещена профессиональная подготовка или переподготовка кадров. Также Евросоюз настоял на принятии подобных санкций третьими странами [3].

Среди последующих санкций также есть те, которые связаны с реализаций экономических проектов в Арктике. Они касаются уже непо- 
средственно европейских компаний, работающих в данном регионе, которым запрещено оказывать всяческую помощь в разведке и добыче сланцевой нефти в глубоководных месторождениях на территории РФ. Это затрагивает не только процессы, связанные с техническим испытанием месторождений, но и с бурением, а также поставкой оборудования для осуществления этих технологических действий и водного транспорта. Послабление санкций возможно только в отношении безопасности человека и окружающей среды.

Третья волна санкций усиливает негативные меры, направленные на снижение продаж, поставок оборудования и экспертной помощи в добыче и поставке нефти из арктических месторождений России (в водах глубже 150 м.; северные акватории за Полярным кругом) [3].

Однако видно, что этим пакетом Европейский союз положительно отреагировал на добычу нефти в месторождениях на небольшой глубине и в сухопутной зоне. Министр природных ресурсов и экологии РФ С.Донской считает, что коррективы к санкциям от 5 декабря 2014 г. позволили зарубежным компаниям определиться с возможностью работы в АЗРФ по проектам на суше [2].

Все вышеперечисленные санкции ограничили или полностью исключили доступ российских компаний к международным финансам, а также инвестициям. Также резко сократилась возможность реализации совместных экономических проектов и покупки зарубежной продукции, необходимой для успешной нефтедобычи в регионе. Можно сказать, что авторитет Росси в связи с данными санкциями было существенно подорван, а экономическое положение - ослаблено.

В ответ на санкции со стороны арктических государств РФ предприняла следующие контрмеры:

1. Ответные санкции, которые предусматривают ограничение или прямой запрет ввоза на российскую территорию ряда категорий товаров. Так, согласно Указу Президента РФ [6], на 1 год введен запрет на ввоз в страну ряда сельскохозяйственных продуктов, сырья и продовольствия из ЕС (в том числе Финляндии), США;

2. Диверсификация экспортной продукции, которая попадает под европейские и американские санкции;

3. Диверсификация импортной продукции, на которые распространяются санкции России.

Помимо этого, Россия своевременно перенаправила потоки экспорта и импорта, тем самым расширив взаимоотношения с влиятельными азиатскими участниками рынка, прежде всего с Китаем: «санкции на самом деле влияют на экономическую логику РФ. Например, отмечается более активная ориентация на Восток и ЮгоВосток. Одновременно будут меняться потоки инвестиций и капитала, создаваться новые модели экономических отношений, которые отвечали государственным интересам» [1]. Активизировавшееся международное сотрудничество с Китаем, в том числе по арктическим вопросам, имеет своей целью компенсацию социальноэкономических показателей в регионе для дальнейшего его развития и освоения.

Несмотря на действующие с 2014 года санкции и приостановление активного сотрудничества РФ с Норвегией и Финляндией, с конца 2016 г. оба этих государства возобновляют торгово-экономические отношения с Российской Федерацией. Financial Times пишет, что это свидетельствует о нежелании данных государств продлевать ограничительные меры и свидетельствует о потеплении в отношениях стран. «Мы позитивно настроены к восстановлению политического диалога, касающегося торговоэкономического сотрудничества с Россией, что уже сделали определенные европейские государства»,- подчеркнула М.Меланд, министр торговли, промышленности и рыболовства Норвегии: «Норвегия стремится к добрососедским отношениям с Россией, особенно на севере, где есть общая граница и общие интересы» [4].

На современном этапе продолжают функционировать приграничные связи. Так, Правительство Мурманской области поддержало инициативу развития горного дела в арктическом регионе, которая предложена финской компанией Spinverse. Ее целью выступает налаживание двустороннего взаимодействия в области устойчивого развития горного дела в Арктике, а именно поддержка проектов в сфере комплексной горной добычи. Участие партнеров из Финляндии в развитии металлургической и горно-химической промышленности Мурманской области имеет перспективы длительного взаимодействия. Инициативу предполагается осуществлять вместе с ведущими горнодобывающими комбинатами Заполярья и самыми крупными финскими технологическими корпо- 
рациями [5]. Северные соседи России понимают, что санкции, принятые против нее, негативно влияют и на их развитие в арктическом регионе, и на международные отношения государств по остальным вопросам. Понимая, что РФ является основным партнером в различных отраслях сотрудничества в Арктике и не только, Норвегия и Финляндия принимают меры, направленные на улучшение межгосударственных отношений стран.

Международные экономические отношения на сегодняшний день являются взаимозависимой системой, в связи с чем норвежские и финские (в составе Евросоюза) санкции существенно влияют на взаимодействие стран в арктическом регионе. С одной стороны, экономические санкции затормозили взаимоотношения РФ с европейскими компаниями, с другой,- они успешно развиваются с восточными. Норвежские санкции и срыв сроков начала освоения Штокмановского месторождения привел к заморозке вопросов упрощения миграционного законодательства, в частности вопросов въезда и пребывания на территории страны и осуществления трудовой деятельности. Значительно замедлилось сотрудничество по подготовке соответствующих специалистов в областях, касающихся освоения Арктики. В ходе сотрудничества с зарубежными странами Россия не усовершенствовала свои технологии морской добычи на шельфе, при производстве и реализации сжиженного газа. Тем не менее, сотрудничество в сфере освоения арктических нефтегазовых месторождений на шельфе продолжается и в условиях санкций, однако, его интенсивность оказывает значительное влияние на темпы освоения новых районов на арктическом шельфе. Таким образом, механизм санкций способствует решению актуальных и прежде оставляемых без внимания задач в российской Арктике.

Основной проблемой экономических санкций является то, что страны, принявшие их против России, сами пострадали от данных ограничений. Другой проблемой выступает желание Норвегии и Финляндии продолжать торговоэкономическое взаимодействие с РФ без возможности отмены принятых совестно с другими европейскими странами ограничений. Трудным также является тот факт, что освоение Арктического региона Россией без использования зарубежных инновационных технологий и оборудования значительно замедлилось. Перспективы развития экономических санкций в Арктике состоят в дальнейшем углублении российского сотрудничества по вопросу освоения региона с азиатскими партнерами.

Таким образом, можно сформулировать следующие рекомендации по решению проблем экономических санкций Норвегии, РФ и Финляндии в Арктике:

1) В долгосрочной перспективе поэтапная, а не одномоментная отмена экономических ограничений всеми странами Европы;

2) В краткосрочной перспективе смягчение санкционных ограничений по вопросу поставки оборудования и технологий;

3) Концентрация на тех сферах сотрудничества стран, которые не подпадают под действие санкций: энергетика (энергетический проект «Северный поток-2»), культура, образование, социальная политика, здравоохранение и т.д.

4) Активное участие России в решении арктических вопросов в рамках Арктического совета, особенно на современном этапе, в период председательства Финляндии.

5) Необходимо увеличить темпы по разработке, созданию и вводу в эксплуатацию инновационной техники, оборудования по добыче и производству нефте- и газопродуктов.

Поэтапная отмена санкций приведет к разрядке международного напряжения и улучшению ситуации в экономике России и европейских стран, которые закрыли для себя перспективный рынок мелководных прибрежных арктических проектов.

Освоение Арктики в условиях антироссийских санкций проходит медленнее, чем раньше, однако от них зависит лишь небольшая часть комплексной работы в регионе. В первую очередь на положении Росси в Арктике сказывается ряд технологических ограничений, что привело к замедлению процессов разведки на арктическом шельфе нефтегазовыми компаниями. Однако в настоящее время это не смогло существенно повлиять на масштабы добычи углеводородов, поскольку доля арктической нефти в них пока не является высокой и будет возрастать только с течением времени. В настоящее время это не представляется возможным из-за ряда проблем: высокие технологические затраты, отсутствие инфраструктуры, недостаток финансовых средств, кадровый голод, негативная экологическая ситуация и т.д. 


\section{Библиографический список}

1. Губин Б.В. Влияние антироссийских санкций на экономическую безопасность страны и меры по их нейтрализации // Экономическая безопасность России: проблемы и перспективы. Материалы II Международной научно-практической конференции. Нижний Новгород, 27-28 мая 2014.- С. 150.

2. ЕС освободил от санкций проекты на суше Арктики // Интерфакс [Электронный ресурс]. URL: http://www. interfax.ru/business/411467 (Дата обращения: 04.04.2020).

3. Муранов, Черняков Общий обзор санкций, введенных ЕС против Российской Федерации - [Электронный документ] URL: http://sanctionsregulations.ru/wp-content/uploads/\%D0\%9E\%D0\%B1\%D1\%89\%D0\%B8\%D0 \%B9-\%D0\%BE\%D0\%B1\%D0\%B7\%D0\%BE\%D1\%80-\%D1\%81\%D0\%B0\%D0\%BD\%D0\%BA\%D1\%86\%D0\%B8\%D 0\%B9-\%D0\%B2\%D0\%B2\%D0\%B5\%D0\%B4\%D0\%B5\%D0\%BD\%D0\%BD\%D1\%8B\%D1\%85-\%D0\%95\%D0\%A1\%D0\%BF\%D1\%80\%D0\%BE\%D1\%82\%D0\%B8\%D0\%B2-\%D0\%A0\%D0\%BE\%D1\%81\%D1\%81\%D0\%B8\%D0\%B9\% D1\%81\%D0\%BA\%D0\%BE\%D0\%B9-\%D0\%A4\%D0\%B5\%D0\%B4\%D0\%B5\%D1\%80\%D0\%B0\%D1\%86\%D0\%B8\%D0 \%B8.pdf (Дата общения 15.04.2019).

4. Норвегия и Финляндия запустили процесс отмены санкций против России.- [Электронный документ].URL: http://baltnews.lt/world/20161202/1016506324.html (Дата обращения 04.04.2020).

5. Трухачев В. Роколл: скала раздора в Атлантике // Электронный сайт «Военное обозрение» [Электронный документ].- URL: http://topwar.ru/35765-rokoll-skala-razdora-vatlantike.html (Дата обращения 07.03.2019).

6. Указ Президента РФ от 6 августа 2014 г. № 560 «О применении отдельных специальных экономических мер в целях обеспечения безопасности Российской Федерации» - [Электронный документ].- URL: https://base. garant.ru/70711352/ (Дата обращения 04.04.2020).

7. Энциклопедический словарь конституционного права. - [Электронный документ]. - URL: http://determiner. ru/termin/sankcii.html (Дата обращения: 04.04.2020). 